\title{
Animal Name: \\ Representation of Human Relations with the Environment
}

\author{
Die Bhakti Wardoyo Putro ${ }^{1}$, Desy Rufaidah ${ }^{2}$, and Sudartomo Macaryus ${ }^{3}$ \\ $\underline{\text { die_bhakti@ustjogja.ac.id }}{ }^{1}$, desy_rifaidah@ustjogja.ac.id ${ }^{2}$, and $\underline{\text { sudartomo@ustjogja.ac.id }}^{3}$ \\ FKIP Universitas Sarjanawiyata Tamansiswa Yogyakarta ${ }^{1}$, FKIP Universitas Sarjanawiyata \\ Tamansiswa Yogyakarta², FKIP Universitas Sarjanawiyata Tamansiswa Yogyakarta ${ }^{3}$
}

\begin{abstract}
Animals are part of the human environment. Humans with their common sense place animals in several categories. In Javanese society there are known terms of kewan alas 'wild animals', kewan galak 'wild animals', iwen 'pets', lulut 'tame', and ingon-ingon 'domestic'. This paper focuses on animal names, to uncover the taxonomy of animal names that exist in Javanese society. With ethnolinguistic methods, preliminary data from library sources is supplemented by field data obtained through observation, participation, and interviews with selected respondents, namely citizens who become breeders or induct animals, such as goats, cattle, buffaloes, and horses. Hypothetically the naming of animals along with the elements that become part and their supporters express human closeness with animals. The closer relationship makes it more creative in naming the parts and environment that become the ecosystem of each animal.
\end{abstract}

Keywords: animals, ecosystems, terms, taxonomy

\section{Introduction}

Animals are living things that are part of the ecosystem of human life. Animals have the potential to become supporters of meeting economic, food, entertainment and labor needs. Animal husbandry has the potential to be a capital investment that can bring economic benefits. Development of animal slaughter provides food for humans that contain high nutritional value and is needed by the human body. The use of animals for the circus is another alternative way to introduce animals to the public that contains entertainment value. Among traditional Javanese farmers, animals also become laborers to attract plows, carts and carts.

Human closeness to animals raises a chain of benefits ranging from energy, meat, dirt, and the ability to reproduce. Humans with common sense have the ability to respond to the environment and arrange taxonomies about their environment, including the environment of animals. The emergence of the term kewan alas 'wild animal', kewan galak 'wild animal', and raja kaya 'domestic animal' shows one of the taxonomies of Javanese society regarding the animals that exist in its environment.

The Semai community has a closeness to animal life. The closeness, among others, appears in the use of animal names to create proverbs [1]. Proverbs as expressions of community wisdom formulated verbally convey intentions indirectly. In Javanese the names of animals are also used to create various expressions, such as parikan and trembling. The use of animal names as a basis for preparing expressions supports socialization and does not pose a threat. Meanwhile, another understanding is a source of threat, as happened in Nigeria. 
Poaching and illegal trade become one of the threats to the decline of perimata, especially chimpanzees in Taraba, Nigeria [2]. Meanwhile, on the Cameroon border a hunting permit can be obtained from the government. However, hunters tend to ignore because the fines are considered light. These two phenomena require better conservation management. Rice sanctions are deemed necessary to make hunters feel deterrent, while officers have the imperative to be firm with offenders. In Indonesia, some animals are also endemic, such as tigers, orangutans, and some animals. The decline in the number and extinction of certain animals makes the names that are left have no natural reference.

\subsection{Name and Introduction Strategy}

Names in animals show the characteristics as a classification, while names in humans show identity characteristics [3]. For pets such as dogs and cats, humans often give names as "identity" but this tends to be a way to facilitate summons and counting. The term identity has a special meaning because it does not become the identity of the animal in question. The more common way to show animal identity is by number. Animal names are used for clinical studies of aphasia patients [4]. Lexically-semantically the name of the animal shows a tendency towards two dimensions, namely typical and familiarity.

The recognition of animal names has the possibility of being conveyed using various media. In the educational environment, animal names are introduced by utilizing digital media [5], [6]. Both offer ways to introduce animal names in English using educational games. Educational games in primary schools as educational aids are seen as more effective, efficient, interactive, and entertaining. It was a challenge for educators to create learning media by utilizing digital technology.

British and American children by Patrick and Tunnicliffe [7] are said to have the same knowledge about animals and plants. Knowledge about animals tends to be better and more complete than about plants. Furthermore, for educational purposes Patrick and Tunnicliffe suggest that teachers use plant and animal props into the classroom and suggest that children interact with animals and plants in their environment. At present it is an alternative to present animal and plant displays, in game, animation or film formats.

\section{Method}

This paper uses the ethnolinguistic method which begins with library data obtained from published writings in the form of books, research reports, articles, and news. The library data is complemented by field data which are carried out through observation, participation and indepth interviews with villagers who raise animals. Interviews were conducted to obtain an explanation of the taxonomy of animal names in the view of Javanese people. In addition to grouping, also the use of elements and parts used by the community.

Data analysis is carried out continuously since the data provision stage. Interpretation of data is carried out contextually and anthropologically by taking into account interdata as a whole. The anthropological context is carried out by linking various cultural activities related to animals, such as rituals and salvation. Anthropological contextual interpretation to obtain information on human relations with animals that shows the introduction, knowledge, and utilization of animals in human life. 


\section{Results and Discussion}

\subsection{Research result}

Animals are one of the living things (folk biology) that are able to move, react to stimuli and become part of the ecosystem of human life. Animals on earth are very diverse and are classified into various categories. In biology, classification is paired with the term taxonomy. Taxonomy is a way of grouping based on certain characteristics (8). Animals are classified into several types, such as based on the presence and absence of the spine (vertebrates and invertebrates), types of food (herbivores, carnivores, and omnivores), symmetrical animal bodies (bilateral and radial), where they live (land, water, land and water), body covering (scaly, slimy, hairy, hairy), locomotor (legs, wings, stomach, abdomen and legs), and how to reproduce (oviparous, viviparous, and ovoviviparous).

In this article, the grouping of animals is examined based on ethnolinguistic studies in the view of Javanese society and taxonomy in biology. The grouping of animals is focused on four-legged pets. Grouping animals into word classes is called taxa. The existing taxa are then grouped into smaller classes which are then called ethnobiological taxonomic categories. Ethnobiology categories are determined using linguistic and taxonomic criteria. The name of the category is unique beginner, life form, generic, specific, and varietal (9).

Based on the unique beginner taxa, kewan 'animal' or sato 'animal' taxa have a life form, namely the term kewan alas 'wild animal', kewan galak 'fierce animal', and raja kaya 'domestic animal' shows one of the Javanese taxonomies about animals in the environment. Generic taxa: kewan alas 'wild animals', such as orangutans, black rhinos, weasels; kewan galak 'beasts', such as boyo 'crocodiles', dragons, ula cobras ob cobras '; and raja kaya 'pet' , such as bulls, cows, buffalos, wedhus goats, and horses. Specific taxa is more like 'cows', such as beef cattle and dairy cows. Varietal taxa of cattle, such as limousine, ordinary metal, super metal, Java Brama. Taksa specific kebo 'buffalo', such as kebo alas 'wild buffalo', kebo kali 'buffalo river', kebo rawa 'buffalo swamp'. Taksa specific wedhus 'goats', such as boer goats, bean goats, randu jawa, saanen goats, etawa crossbreed goats, and etawa goats. Taksa specific jaran 'horse', such as local horses and imported horses. Varietal taxa of local horses, such as Sumatera horses, brass horses, Sumba horses. Varietal taxa imports, such as racehorses and cavalry horses.

\subsection{Discussion}

Animals are one of the living things (folk biology) that are able to move, react to stimuli and become part of the ecosystem of human life. Animals on earth are very diverse and are classified into various categories. In biology, classification is paired with the term taxonomy. Taxonomy is a way of grouping based on certain characteristics [8]. Animals are classified into several types, such as based on the presence and absence of the spine (vertebrates and invertebrates), types of food (herbivores, carnivores, and omnivores), symmetrical animal bodies (bilateral and radial), where they live (land, water, land and water), body coverings (scaly, slimy, hairy, hairy), locomotor (legs, wings, stomach, abdomen and legs), and how they multiply (oviparous, viviparous, and ovoviviparous).

In this article, the grouping of animals is examined based on ethnolinguistic studies in the views of Javanese society and taxonomies in biology. The grouping of animals is focused on four-legged pets in Javanese society, namely lembu 'cattle', kebo'buffalo', wedhus 'goats', and jaran 'horse'. Grouping animals into word classes is called taxa (taxa). The existing taxa are 
then grouped into smaller classes which are then called ethnobiological taxonomic categories. Ethnobiology categories are determined using linguistic and taxonomic criteria. The name of the category is unique beginner, life form, generic, specific, and varietal [9].

Based on the unique beginner taxa, kewan 'animal' or sato 'animal' taxa have a life form, namely the term kewan alas 'wild animal', kewan galak 'fierce animal', and raja kaya 'domestic animal' shows one of the Javanese taxonomies about animals in the environment. The taxonomy on the life form taxa shows the relationship and the extent of the closeness between animals and humans. The kewan alas 'wild animal' is an animal which is possibly a kewan galak 'wild animal' and not a raja kaya 'pet' who normally lives in the forest or the wild. Taxa kewan alas 'wild animal' is a life form taxa that has generic taxa, such as orangutans, black rhinos, ferrets, and so on. Taxa kewan galak 'wild animal' is a life form taxa that is an animal that is possible to be classified in the kewan alas category 'wild animal' and is not classified or possible in the raja kaya category of 'pets'. The kewan galak taxa 'wild animal' in the life form taxa has generic taxa, such as boyo 'crocodile', komodo, ula cobra 'cobra snake', and so on. Taksa raja kaya 'domestic animals' which has the equivalent words, iwen 'pets' and ingon-ingon 'pets'. The difference between a kewan alas and a raja kaya, that is, kewan alas living freely and looking for his own food, while a raja kaya is an animal that lives with restricted freedom and is unable to find food alone. Then which term is used for pets? In Javanese society, the terms raja kaya and iwen are unfamiliar and non-functional terms in daily communication. The term that is often found is the word ingon-ingon. The term ingon-ingon consists of the primary leksem ingon 'eat' and then experience repetition to ingoningon which is interpreted as 'pet'. Taxa raja kaya 'domestic animals' or ingon-ingon have generic taxa, such as lembu 'cow', kebo 'buffalo', wedhus 'goat', and jaran 'horse', and so on.

In general, animals such as lembu 'cow', wedhus 'goat', kebo 'buffalo', and jaran 'horse' are types of animals that are classified as herbivorous animals, which are plant-eating animals. In addition, it is also included in the viviparous group, which is an animal that breeds by giving birth. In Javanese society, especially farmers, lembu, wedhus, kebo, and jaran are very important animals.

Lembu 'ow' is one of the pets that the owner is usually a farmer or businessman. Leksem ox is intended for naming juvenile or adult cattle. Meanwhile, to name the calf named after the pedet. The 'ox' cattle taxa is a generic taxa that has specific taxa, namely beef cattle and dairy cows. Ox has the potential to be a supporter to meet the needs of the economy, food, entertainment and labor. Dairy cows have the potential to be a capital investment that can bring economic benefits. Dairy cows produce milk and cheese. Development of cut cattle provides food for humans that contain high nutritional value and are needed by the human body. Slaughtered beef that will and has been processed is called iwak sapi. In Javanese society, the word iwak does not mean 'fish' but has the meaning 'side dishes'. To distinguish the meaning of the word iwak which means real fish or side dishes can be seen from the lexemes that follow the side dish, such as iwak sapi 'beef', iwak pitik 'chicken', iwak tahu 'tofu', and so on.

Utilization of bulls is not only on economic matters and food needs, oxen can have entertainment value, for example, it can be seen in the Madurese community. As a traditional ceremony, cow racing is regularly held every year. Cow racing as another alternative to introduce animals to the community that contains the value of tradition and entertainment. In addition, cattle are also employed in the fields. Among traditional Javanese farmers, cattle also become laborers to attract plows, carts and carts. Not only energy, cow dung, namely letong used as fertilizer to fertilize plants in the fields. Ox taxa is a specific taxa that has varietal taxa, such as limousine, ordinary metal, super metal, Java brama. 
The "buffalo" kebo (bubalus boss) is one of the ruminant animals that are kept for meat or energy for plowing the fields. In contrast to the benefits or uses of buffalo, the word buffalo in Indonesian figuratively has a negative connotation which means stupid person. The word smells of juda is used in several proverbs such as, buffalo gore a child just pretend or not mean it'; buffalo has milk 'someone who does good or takes pains, but someone else gets praise'; tapered buffalo; famous criminals'; buy buffalo in the field 'buy something without seeing the item to buy'; like a buffalo being matched by the nose 'always according to its stupidity'; etc.

Taxa kebo 'buffalo' is a generic taxa that has specific taxa, such as kebo alas liar wild buffalo ', kebo kali' river buffalo ', kebo swamp“ buffalo swamp '. "buffalo" kebo. Kebo is one of the livestock that is almost the same utilization as an ox. However, kebo is not much in demand and is not generally maintained. For some regions in Indonesia, for example in Java, Sumatra, Toraja, and Sumbawa, kebo has social, cultural value, and is used as a dowry in marriage. In addition, kebo in South Sulawesi is used as a means of payment of fines, if someone has violated customary law. In Kudus, Central Java, kebo is used as a substitute for beef. This relates to the history of the city of Kudus. In ancient times many people in Kudus followed Hinduism and cows were sacred animals which could not be slaughtered and eaten. When the Islamic religion entered Kudus, Sunan Kudus forbade his followers to slaughter and eat cows during the Eid al-Adha feast day. They replaced it with buffalo to respect the people who converted to Hinduism. Until now, all processed beef has been replaced by buffalo. This has become a symbol of religious tolerance in Kudus.

Utilization of kebo for Javanese people is almost the same as using cattle. In terms of economy and food needs, kebo is consumed into several processed ingredients such as satai and soto. In some areas, especially Kudus, consuming kebo meat is a tradition that has been passed down for generations. In addition, kebo is also employed in the fields. Kebo manure is also used by farmers as fertilizer to fertilize crops. Among peasants, kebo becomes a labor force to attract plows. In addition, the waste used by farmers to fertilize kebo plants. Taksa kebo is a specific taxa that has variety taxa, such as buffalo Gayo, Java, Kalal Kalalel, Kalang Kaltim, Kuntu, Moa, Pampangan, Simeulue, West Sumatra, North Sumatra, Sumbawa and Toraja.

Wedhus is a pet that is usually used for ivory, milk or fur, ruminant animals and grasseaters. Like buffalo, the word wedhus often has a negative connotation which is usually used as a curse. Wedhus leksem is intended for naming juvenile or adult goats. Meanwhile, to name the son Wedhus referred to as Cempe. Taksa wedhus is a generic taxa that has a specific ed goat 'wedhus taxa, such as boer goats, bean goats, rawa jawa goats, saanen goats, etawa crossbreed goats, and etawa goats. Wedhus has the potential to be a supporter to meet economic and food needs. Wedhus breeding has the potential to be a capital investment that can bring benefits economically. Wedhus produces meat, milk, and sometimes the feathers are also used. Wedhus provides food for humans that contain high nutritional value and is needed by the human body. Wedhus have a high sale value, especially near or during the Day of Victims for Muslims. For people who are unable to sacrifice cows, Wedhus is an affordable alternative for the middle to lower classes.

Thejaran 'horse' in Latin equus caballus is one of the pets that are used as vehicles (mounts or transportation), breastfeeding animals, and one-legged. Jaran leksem is intended for young or adult horses. As for children jaran called the term belo. Horses for the general public are indeed not one of the animals that are commonly kept. Only people with a specific intention to take care of it, such as the wealthy who aim as a ride animal and the person who works as a driver who aims as a means of transportation or transportation. In addition, jaran 
also brings economic benefits by producing meat and milk. Taksa jaran 'horse' is a generic taxa that has specific taxa, namely local horses and imported horses. Varietal taxa of local horses, such as Sumatran horses, brass horses, Sumba horses. Varietal taxa imports, such as racehorses and cavalry horses, Arabian horses, akhal, falabella, curly, and black forest.

\section{Conclusion}

Humans classify animals in several categories or taxonomies. In Javanese society there are known terms as 'wild animals', fierce animals 'wild animals', iwen 'pets', 'tame' lulut, and 'domestic' ingons. The grouping of animals is examined based on ethnolinguistic studies in the view of Javanese society and taxonomy in biology. The grouping of animals is focused on four-legged pets. Grouping animals into word classes is called taxa (taxa) which are further grouped into classes, namely unique beginner, life form, generic, specific, and varietal. Based on the unique beginner taxa, 'animal' or sato 'animal' taxa have a life form, namely the term 'wild animal', 'fierce animal', and the rich king of 'domestic animal' shows one of the Javanese taxonomies about animals in the environment. Generic taxa: animal base 'wild animals', such as orangutans, black rhinos, weasels; fierce animals 'beasts', such as boyo 'crocodiles', dragons, ula cobras ob cobras '; and rich 'pet' kings, such as bulls, cows, buffalos, wedhus goats, and horses. Specific taxa is more like 'cows', such as beef cattle and dairy cows. Varietal taxa of cattle, such as limousine, ordinary metal, super metal, Java Brama. Taksa specific kebo 'buffalo', such as kebo alas 'wild buffalo', kebo kali 'buffalo river', kebo swamp 'buffalo swamp'. Taksa specific wedhus 'goats', such as boer goats, bean goats, randu jawa, saanen goats, etawa crossbreed goats, and etawa goats. Taksa specific jaran 'horse', such as local horses and imported horses. Varietal taxa of local horses, such as Sumatran horses, brass horses, Sumba horses. Varietal taxa imports, such as racehorses and cavalry horses.

\section{References}

[1] Mahali, Saidatul Nornis Hji dan Saamah MRP. Haiwan Sebagai Perlambangan Dalam Peribahasa Orang Semai. 2013;13(February):83-98.

[2] Nyanganji, Gilbert; Fowler, Andrew; McNamara, Aylin; dan Sommer V. Monkeys and Apes as Animals and Humans: Ethno-Primatology in Nigeria's Taraba Region. V Sommer C Ross (eds), Primates Gashaka, Dev Primatol 101 Prog Prospect. 2011;35.

[3] Borkfelt S. What's in a Name? - Consequences of Naming Non-Human Animals. 2011;116-25.

[4] Laiacona, Marcella; Scotti, Stefania; Allamano, Nadia; Lorenzi, Lorena; Capitani E. Exploring The Semantic Category of Animals: Some Useful Indices for A Qualitative Study of Name Production and Their Validation in a Patient. J Neurolinguistics. 2011;24:70-88.

[5] Saputra, Adam; Beny; dan Nugroho A. Perancangan Edukasi Pengenalan Nama Hewan dalam Bahasa Inggris (Studi Kasus: SDN.58/Vii Teluk Rendah Sarolangun). J Ilm Media Process. 2014;9(1).

[6] Septiani NA, Sulaiman T. Perancangan Animasi Interaktif Mengenal Nama Binatang Dalam Bahasa. 2018;XX(2).

[7] Patrick, Patricia dan Tunnicliffe SD. What Plants and Animals Do Early Childhood and Primary Students' Name? Where Do They See Them? J Sci Educ Technol. 
$2011 ; 20(5)$.

[8] Kurniawan D, Amirudin A. Pengembangan Aplikasi Sistem Pembelajaran Klasifikasi ( Taksonomi ) dan Tata Nama Ilmiah ( Binomial Nomenklatur ) pada Kingdom Plantae ( Tumbuhan ) Berbasis Android. 2015;3(2):120-8.

[9] Suhandono. Klasifikasi Folk Biologi dalam Bahasa Jawa, Sebuah Pengamatan Awal. 2000;X11:225-30. 